\title{
Application of a roller conveyor type plasma disinfection device with fungus-contaminated citrus fruits
}

\author{
Akikazu Sakudo ${ }^{1,2^{*}}$ and Yoshihito Yagyu ${ }^{3}$
}

\begin{abstract}
Efficient methods to achieve the safe decontamination of agricultural products are needed. Here, we investigated the decontamination of citrus fruits to test the antifungal potential of a novel non-thermal gas plasma apparatus, termed a roller conveyer plasma instrument. This instrument generates an atmospheric pressure dielectric barrier discharge (APDBP) plasma on a set of rollers. Penicillium venetum was spotted onto the surface of the fruit or pericarps, as well as an aluminium plate to act as a control, before performing the plasma treatment. The results showed that viable cell number of $P$. venetum decreased with a decimal reduction time ( $D$ value or estimated treatment time required to reduce viable cell number by $90 \%$ ) of $0.967 \mathrm{~min}$ on the aluminium plate, $2.90 \mathrm{~min}$ and $1.88 \mathrm{~min}$ on the pericarps of 'Kiyomi' (Citrus unshiu $\times$ C. sinensis) and 'Kawano-natsudaidai' (C. natsudaidai) respectively, and 2.42 min on the surface of 'Unshu-mikan' (C. unshiu). These findings confirmed a fungicidal effect of the plasma not only on an abiotic surface (aluminium plate) but also on a biotic surface (citrus fruit). Further development of the instrument by combining sorting systems with the plasma device promises an efficient means of disinfecting citrus fruits during food processing.
\end{abstract}

Keywords: Citrus, Disinfection, Dielectric barrier discharge, Fruits, Fungi, Plasma

\section{Introduction}

Measures to control plant pathogens in primary food production are important for food quality management (Strange and Scott 2005). Losses caused by pathogens, animals and weeds are estimated to reduce global food productivity by $20-40 \%$ (Savary et al. 2012). According to reports from the Ministry of Agriculture, Forestry and Fisheries of Japan in 2019, 78,300 tons of citrus fruit was lost due to these issues from a total of 746,700 tons (Ministry of Agriculture, Forestry and Fisheries 2020), which cost 15,660 million yen (provisional price: 200 yen $/ \mathrm{kg}$ ). One of the major causes for these losses is fungal infection that occurs during the storage of citrus fruit after harvest.

\footnotetext{
*Correspondence: akikazusakudo@gmail.com

1 School of Veterinary Medicine, Okayama University of Science, Imabari, Ehime, Japan

Full list of author information is available at the end of the article
}

Fungi are one of the major risk factors for plant diseases. For decades pesticides have been used to treat citrus fruit, but these chemicals are now known to pose a threat to human and animal health (WHO and FAO 1996; FAO and WHO 2016). Furthermore, efficient transportation systems for agricultural products have accelerated the spread of fungal diseases. As a consequence, these plant pathogens have a major environmental and economic impact because they can greatly reduce crop production. Therefore, an efficient and safe technology to disinfect foods during food processing is required. These considerations prompted us to develop an instrument that could be used to eradicate fungi from agricultural products.

Thermal disinfection technologies sometimes reduce the quality and nutritional value of foods (Huang et al. 2009; Wang et al. 2013). As a result, fresh produce such as fruits are usually disinfected with a solution of chlorine. However, residual chlorine can have a carcinogenic effect on humans and therefore represents a potential health
Springer Open (c) The Author(s) 2021. This article is licensed under a Creative Commons Attribution 4.0 International License, which permits use, sharing, adaptation, distribution and reproduction in any medium or format, as long as you give appropriate credit to the original author(s) and the source, provide a link to the Creative Commons licence, and indicate if changes were made. The images or other third party material in this article are included in the article's Creative Commons licence, unless indicated otherwise in a credit line to the material. If material is not included in the article's Creative Commons licence and your intended use is not permitted by statutory regulation or exceeds the permitted use, you will need to obtain permission directly from the copyright holder. To view a copy of this licence, visit http://creativeco mmons.org/licenses/by/4.0/. 
risk (Rico et al. 2007; Allende et al. 2008; Chen and Hung 2017). Several alternative non-thermal disinfection technologies such as radiation (Molnár et al. 2018), hydrostatic pressure (Wang et al. 2016), ozone (Venta et al. 2010), electrolyzed water (Rahman et al. 2016), electrically charged disinfectant (Nakashima et al. 2017; Sakudo et al. 2020a, b), electroporation (Uemura and Isobe 2002), high power ultrasound (Bermudez-Aguirre 2017), high pressure (Ogawa et al. 2000), pulsed electric field (Garner 2019) and ultraviolet light (Manzocco et al. 2011), have been used to disinfect fruit. Unfortunately, some of these technologies give disappointing levels of disinfection or require excessive setup costs with specially trained personnel (Sakudo and Shintani 2010).

Plasma is often referred to as the fourth state of matter. Treatment with plasma is a promising non-thermal technique for decontaminating food products and represents a potential alternative to conventional disinfection methods (Afshari and Hosseini 2014; Ito et al. 2018; Sakudo et al. 2019; Charoux et al. 2020; Braný et al. 2020). A variety of bacteria and viruses as well as fungi have been shown to be inactivated by gas plasma treatment (Sakudo and Shintani 2010; Afshari and Hosseini 2014; Shintani and Sakudo 2016; Bermudez-Aguirre 2019). Recently, we developed a plasma device, known as a roller conveyer plasma instrument, which generates plasma via an atmospheric pressure dielectric barrier discharge (APDBD) (Toyokawa et al. 2017, 2018). By connecting to a wire motor, the roller conveyer plasma instrument can disinfect crops on rollers during the sorting process. Thus, the roller conveyer plasma instrument is a promising means of efficiently disinfecting crops. However, to date, the disinfection potential of this instrument for fruits contaminated with fungus remains unclear.

Here, we investigated the disinfection efficiency of the roller conveyer plasma instrument using citrus fruits contaminated with a fungus.

\section{Materials and methods}

\section{Roller conveyer plasma instrument}

We used a roller conveyer plasma instrument, which was previously reported (Toyokawa et al. 2017, 2018). The gas plasma apparatus comprises rolling electrodes and a high voltage power supply. The electrode is made up of a plastic rod (30 mm diameter) covered with a thin aluminium and silicon sheet $(0.5 \mathrm{~mm}$ thickness), which was placed at an interval of $50 \mathrm{~mm}$ between a high voltage electrode and an earth electrode. The high voltage electrode was connected to an alternating power supply $\left[\mathrm{V}_{\mathrm{pp}}\right.$ (peak-to-peak voltage $)=10 \mathrm{kV}$; Frequency $=9-11 \mathrm{kHz}$; LHV-10AC, Logy Electric Co., Ltd., Tokyo, Japan]. The voltage waveforms in the steady condition (without any object placed on the electrodes) and in the object treatment condition (with an aluminium plate or citrus fruit) showed $\mathrm{V}_{\mathrm{pp}}=11.87 \mathrm{kV}$ (maximal peak $=+6.56 \mathrm{kV}$; minimal peak $=-5.31 \mathrm{kV}$ ) and Frequency $=8.85 \mathrm{kHz}$ in both cases (Additional file 1: Figure S1). The apparatus generated APDBD plasma in air.

\section{Fungal cultures and APDBD treatment}

Penicillium venetum [American Type Culture Collection (ATCC) 16025] and Aspergillus brasiliensis (ATCC 16404) were used as test organisms in this study. The colonies that appeared after culturing the fungi on Potato Dextrose Agar (PDA) medium (FUJIFILM Wako Pure Chemical Corporation, Osaka, Japan) for 2 weeks were suspended in $1 \mathrm{ml}$ of sterilized distilled water (Otsuka Pharmaceutical Co., Ltd., Tokyo, Japan). A $20 \mu \mathrm{l}$ aliquot of fungal suspension was spotted onto either an aluminium plate $(0.3 \mathrm{~mm}$ thickness), the pericarps of 'Kiyomi' $(C$. unshiu $\times$ C. sinensis) and 'Kawano-natsudaidai' (C. natsudaidai), or the surface of 'Unshu-mikan' (C. unshiu). The different samples were then subjected to APDBD treatment. Before treatment, the spots were air-dried and then set onto the grounding position. Plasma was generated at the grounding position between the silicon sheet and either the aluminium plate or the pericarp/surface of the citrus fruit. The plasma-treated fungal samples were suspended in sterilized distilled water (Otsuka Pharmaceutical Co., Ltd.) and the number of colony-forming units (CFU) per ml measured by calculating the colony number of the fungi on PDA plate medium after incubation at $25^{\circ} \mathrm{C}$ for 3 days.

\section{Determination of decimal reduction time ( $D$ value)}

$D$ value was defined as the treatment time required for decreasing the original number of viable cells by $90 \%$. The following equation was employed for this calculation:

$$
D=1 /(\Delta \log \mathrm{N} / \Delta \mathrm{t}),
$$

where $\Delta t$ is the time for a one $\log _{10}$ reduction in viable cells and $\Delta \log N$ is the logarithmic value of the changes in the CFU/ml of fungi after APDBD treatment (Sakudo and Shintani 2010).

\section{Real-time polymerase chain reaction (PCR)}

The APDBD-treated spots were taken up in distilled water (Otsuka Pharmaceutical Co. Ltd.) and boiled for 15 min to extract the genomic DNA. The resultant samples were subjected to real-time PCR analysis to quantify intact genomic DNA using Takara SYBR Premix Ex TaqTM II (Tli RNaseH Plus, Takara Bio Inc.) and specific primers for Penicillium 28S rDNA D1/D2 region (target size: $107 \mathrm{bp}$ ), including Forward primer (5'-GGG ACG TCA TAG AGG GTG AG-3') and Reverse primer 
(5'-CCA CCC ATT TAG AGC TGC AT-3'), as well as for Aspergillus 28S rDNA D1/D2 region (target size:159 bp), including Forward primer (5'-CGG AGT CCG CAT TGT AAT TT- $\left.3^{\prime}\right)$ and Reverse primer (5'-AGC TGC ATT CCC AAA CAA CT-3'). Amplification conditions were as follows. After heating at $95^{\circ} \mathrm{C}$ for $30 \mathrm{~s}$, the fluorescence intensity of the samples was measured during the PCR comprising 40 cycles of $95^{\circ} \mathrm{C}$ for $5 \mathrm{~s}$ and $60^{\circ} \mathrm{C}$ for $30 \mathrm{~s}$ using a Thermal Cycler Dice Real-time System (Takara Bio Inc.). The amplified DNA was verified by dissociation curve analysis. The PCR product was sized by agarose gel electrophoresis.

\section{Statistical analysis}

The results are shown as the mean \pm SEM (standard error of the mean) of experiments, which were performed in triplicate. Non-repeated analysis of variance (ANOVA) followed by Bonferroni correction was employed to the statistical analysis of significant difference using the GraphPad Prism 7.02 software (GraphPad Prism Software Inc., La Jolla, CA).

\section{Results}

Decrease in the viable cell number of $P$. venetum spotted onto an aluminium plate after APDBD treatment

We investigated the changes in the viable cell number after APDBD treatment of $P$. venetum using a roller conveyor plasma instrument. Initially, a $20 \mu \mathrm{l}$ aliquot of fungal suspension was spotted onto an aluminium plate, air-dried, and treated with APDBD for 0,1 , or $2 \mathrm{~min}$. Viable cell counts were then performed. The results of viable cell numbers were $1.73 \times 10^{7} \pm 0.20 \times 10^{7} \mathrm{CFU} / \mathrm{ml}$ at $0 \mathrm{~min}$, but significantly decreased to $1.17 \times 10^{6} \pm 0.65 \times 10^{6} \mathrm{CFU} / \mathrm{ml}$ at $1 \mathrm{~min}$ and $1.50 \times 10^{5} \pm 0.23 \times 10^{5} \mathrm{CFU} / \mathrm{ml}$ at $2 \mathrm{~min}$ treatment time (Fig. 1). From the data, $D$ value (decimal reduction time), which is the estimated treatment time required to reduce the number of viable microorganisms by $90 \%$, was $0.967 \mathrm{~min}$.

\section{Decrease of viable cell number of $A$. brasiliensis after APDBD treatment}

The change in the viable cell number of $A$. brasiliensis after plasma treatment was investigated using a roller conveyor type plasma instrument. A $20 \mu \mathrm{l}$ aliquot of fungal suspension was spotted onto an aluminium plate, airdried, and treated with APDBD for $0,1,2$, or 5 min. Viable cell number at 0 min was $1.25 \times 10^{7} \pm 0.04 \times 10^{7} \mathrm{CFU} /$ $\mathrm{ml}$, whereas the APDBD treatment significantly decreased viable count to $5.37 \times 10^{5} \pm 2.48 \times 10^{5} \mathrm{CFU} /$ $\mathrm{ml}$ at $1 \mathrm{~min}, 5.47 \times 10^{4} \pm 2.17 \times 10^{4} \mathrm{CFU} / \mathrm{ml}$ at $2 \mathrm{~min}$, and $1.62 \times 10^{4} \pm 0.38 \times 10^{4} \mathrm{CFU} / \mathrm{ml}$ at $5 \mathrm{~min}$ (Fig. 2). Based on the data from 0 to $2 \mathrm{~min}$, the $D$ value was $0.826 \mathrm{~min}$.

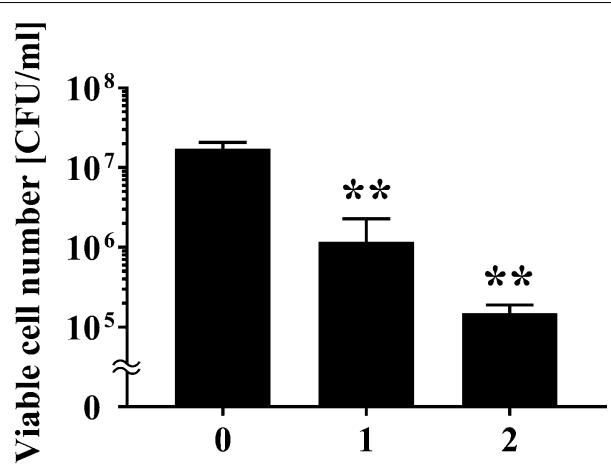

Plasma treatment [min]

Fig. 1 Viable cell number of $P$. venetum on an aluminium plate following APDBD treatment. The viable cell number of $P$. venetum on the contaminated aluminium plate at each individual APDBD treatment time $(0,1$, or $2 \mathrm{~min})$ is expressed as colony forming units (CFU) per $\mathrm{ml}$. Differences where $\left.p<0.011^{(* *}\right)$ versus control ( $0 \mathrm{~min}$ ) were considered significant when verified by the non-repeated measured ANOVA followed by the Bonferroni correction

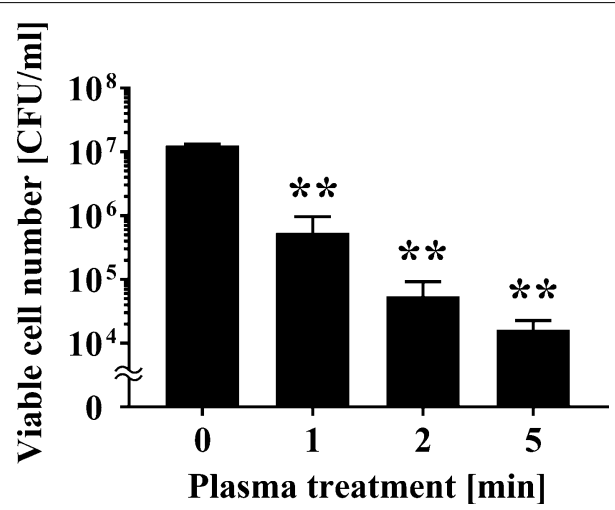

Fig. 2 Viable cell number of Aspergillus brasiliensis spotted onto an aluminium plate following APDBD treatment. Viable cell number of A. brasiliensis spotted onto an aluminium plate, expressed as CFU/ml, after different APDBD treatment times $(0,1,2$, or $5 \mathrm{~min})$. Differences where $p<0.01{ }^{(*)}$ versus Control $(0 \mathrm{~min})$ were considered significant when verified by the non-repeated measured ANOVA followed by the Bonferroni correction

\section{The effect of plasma treatment on DNA of $P$. venetum and $A$. brasiliensis}

We analyzed the effect of plasma treatment on Penicillium and Aspergillus DNA by performing real-time PCR of the $28 \mathrm{~S}$ rDNA D1/D2 region. The real-time PCR analysis of $P$. venetum $28 \mathrm{~S}$ rDNA D1/D2 showed that the levels of intact DNA were $93.21 \pm 12.10 \%$ at $1 \mathrm{~min}, 61.34 \pm 18.11 \%$ at $2 \mathrm{~min}$, but significantly decreased to $11.98 \pm 5.39 \%$ at $5 \mathrm{~min}$, when compared with the Control $(0 \mathrm{~min})(100.00 \pm 2.54 \%)$ (Fig. 3). In addition, the results of the real-time PCR analysis 


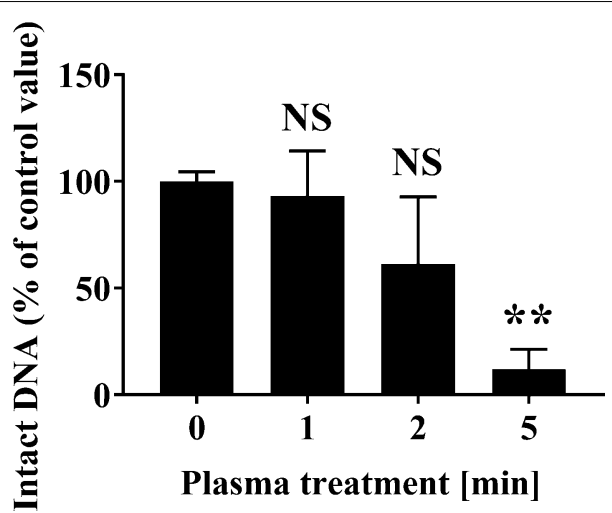

Fig. 3 Changes to fungal DNA (28S rDNA) of Penicillium venetum spotted onto an aluminium plate following APDBD treatment. The level of intact $28 \mathrm{~S}$ rDNA from $P$. venetum spotted onto an aluminium plate was quantified by real-time PCR. The level of the corresponding amplified product for the 0 min sample was assigned a value of $100 \%$. Differences where $\left.p<0.01{ }^{* *}\right)$ versus Control $(0 \mathrm{~min})$ were considered significant when verified by the non-repeated measured ANOVA followed by the Bonferroni correction. NS means no significant difference compared to Control (0 min)
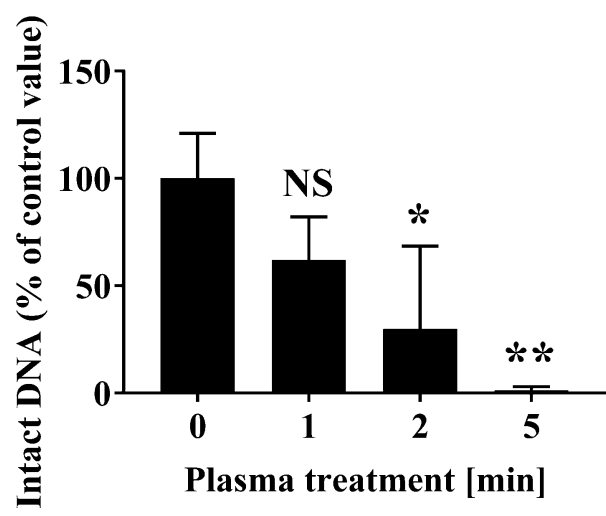

Plasma treatment [min]

Fig. 4 Changes to fungal DNA (28S rDNA) of A. brasiliensis spotted onto an aluminium plate following APDBD treatment. The level of intact 285 rDNA from A. brasiliensis spotted onto an aluminium plate was quantified by real-time PCR. The level of the corresponding amplified product for the 0 min sample was assigned a value of $100 \%$. Differences where $\left.p<0.05^{*}\right)$ and $p<0.01\left(^{* *}\right)$ versus Control ( $\left.0 \mathrm{~min}\right)$ were considered significant when verified by the non-repeated measured ANOVA followed by the Bonferroni correction. NS means no significant difference compared to Control (0 min)

of $A$. brasiliensis 28S rDNA D1/D2 showed the levels of intact DNA were $61.95 \pm 11.65 \%$ at $1 \mathrm{~min}$, but significantly decreased to $29.93 \pm 22.20 \%$ at $2 \mathrm{~min}$ and $1.25 \pm 0.97 \%$ at $5 \mathrm{~min}$, when compared with the Control (0 min) (100.00 $\pm 12.08 \%)$ (Fig. 4).
Decrease in the viable cell number of $P$. venetum spotted onto the pericarp of citrus fruits after APDBD treatment Next, we investigated changes in the viable cell number of $P$. venetum spotted onto the pericarps of citrus fruits after APDBD treatment. A $20 \mu \mathrm{l}$ aliquot of fungal suspension was spotted onto the pericarps of 'Kiyomi' (Citrus unshiu $\times$ C. sinensis) or 'Kawano natsudaidai' (C. natsudaidai) and air-dried. Samples were then subjected to APDBD treatment for 0,1 , or $2 \mathrm{~min}$. The spots were subsequently collected with a sterilized cotton swab. The results of viable cell number on 'Kiyomi' was $5.67 \times 10^{7} \pm 1.20 \times 10^{7} \mathrm{CFU} / \mathrm{ml}$ at $0 \mathrm{~min}$, but significantly decreased to $2.60 \times 10^{7} \pm 0.61 \times 10^{7} \mathrm{CFU} / \mathrm{ml}$ at $1 \mathrm{~min}$ and $1.17 \times 10^{7} \pm 0.09 \times 10^{7} \mathrm{CFU} / \mathrm{ml}$ at $2 \mathrm{~min}$ (Fig. 5a). Viable cell number on 'Kawano natsudaidai' was $3.20 \times 10^{7} \pm 0.32 \times 10^{7} \mathrm{CFU} / \mathrm{ml}$ at $0 \mathrm{~min}$, but significantly decreased to $5.40 \times 10^{6} \pm 1.11 \times 10^{6} \mathrm{CFU} / \mathrm{ml}$ at $1 \mathrm{~min}$ and $2.73 \times 10^{6} \pm 0.12 \times 10^{6} \mathrm{CFU} / \mathrm{ml}$ at $2 \mathrm{~min}$ (Fig. $5 \mathrm{~b}$ ). From this data, the $D$ value for 'Kiyomi' was $2.90 \mathrm{~min}$, while that for 'Kawano-natsudaidai' was $1.88 \mathrm{~min}$.

Decrease in the viable cell number of $P$. venetum spotted onto the surface of citrus fruits after APDBD treatment Finally, we examined whether the roller conveyer plasma instrument was effective at disinfecting the surface of citrus fruits contaminated with fungus. A schematic representation of the roller conveyer plasma instrument is shown in Fig. 6. The light emitted during operation of the instrument is highlighted in Fig. 7. To investigate the disinfection effect of the plasma device, a $20 \mu \mathrm{l}$ aliquot of fungal suspension was spotted onto the surface of $C$. unshiu, air-dried, and then plasma-treated for 0, 0.5, or $1 \mathrm{~min}$. The spots were collected with a sterilized cotton swab. The results demonstrated that 1 min treatment with APDBD gave a significant disinfection effect for citrus fruit contaminated with $P$. venetum (Fig. 8). The results of viable cell number were $6.30 \times 10^{7} \pm 0.49 \times 10^{7} \mathrm{CFU} / \mathrm{ml}$ at $0 \mathrm{~min}$ and unchanged at $6.30 \times 10^{7} \pm 0.90 \times 10^{7} \mathrm{CFU} /$ $\mathrm{ml}$ after $0.5 \mathrm{~min}$ treatment, but a significant decrease to $2.43 \times 10^{7} \pm 0.16 \times 10^{7} \mathrm{CFU} / \mathrm{ml}$ after $1 \mathrm{~min}$ treatment. Based on this data, the $D$ value was $2.42 \mathrm{~min}$.

\section{Discussion}

Recently, there has been significant interest in the potential antifungal application of plasma technology in the food industry. The antifungal effect of plasma on the food matrix has been studied using four different types of device; namely dielectric barrier discharge (DBD) plasma, plasma jet, corona-based plasma and microwavepowered plasma. P. digitatum on C. unshiu could be inactivated by DBD plasma (Yagyu et al. 2016). A. flavus on walnuts was also inactivated by a plasma jet (Amini and 



Fig. 5 Viable cell number of $P$. venetum spotted onto the pericarp of citrus fruits following APDBD treatment. The viable cell number is expressed as CFU per $\mathrm{ml}$. CFU/ml of P. venetum present on the contaminated pericarps of $\mathbf{a}^{\prime}$ Kiyomi' (C. unshiu $\times$ C. sinensis) and $\mathbf{b}$ 'Kawano-natsudaidai' (C. natsudaidai) at each individual APDBD treatment time $(0,1$, or $2 \mathrm{~min})$ are shown. Differences where $p<0.05\left({ }^{*}\right)$ and $p<0.01\left({ }^{* *}\right)$ versus control $(0 \mathrm{~min})$ were considered significant when verified by the non-repeated measured ANOVA followed by the Bonferroni correction

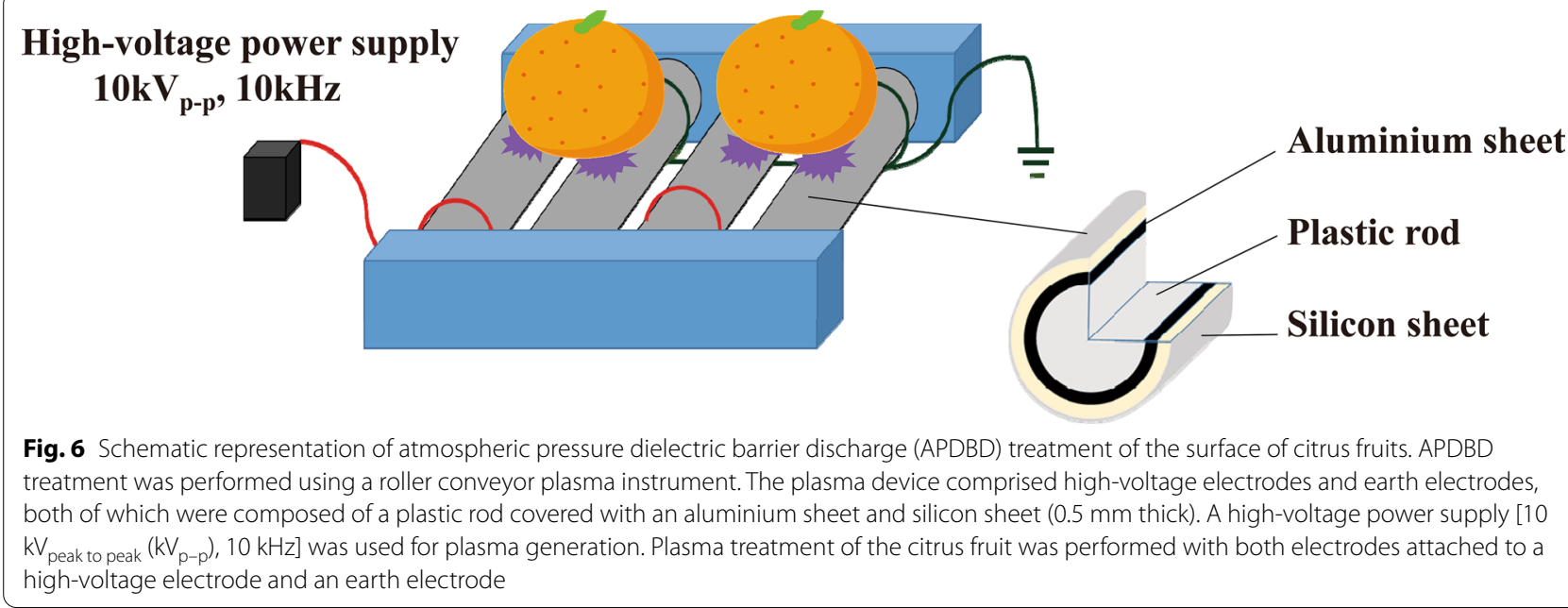

Ghoranneviss 2016). Corona-based plasma was shown to inactivate molds on cherry tomatoes (Lee et al. 2018) and broccoli seeds (Kim et al. 2017a). Microwave-powered plasma was effective at inactivating A. brasiliensis on onion powder (Kim et al. 2017b), and A. flavus on red peppers (Kim et al. 2014), as well as P. italicum on $C$. unshiu (Won et al. 2017).

Unfortunately, however, argon, nitrogen or helium are required as the inlet gas for operation of these devices, which makes them too costly to operate at scale (Moisan et al. 2001). Moreover, the sample box must be maintained at a low pressure, preventing the practical application of this new technology (Moisan et al. 2001). Recently, we developed a new type of roller conveyer instrument that generates plasma in an open system at atmospheric pressure. This device may provide a cost effective method for disinfecting agricultural products in a continuous process without using expensive inlet gases or having to maintain a low pressure environment. Our present results show that the roller conveyer instrument, which generates plasma on the basis of APDBD, can be used to efficiently disinfect fruit contaminated with Penicillium sp. (Figs. 1, 5 and 8) as well as Aspergillus sp. (Fig. 2).

Our experiments showed that plasma treatment of fungi-contaminated citrus fruits using the roller conveyer plasma instrument for 1 min resulted in a disinfection effect (Fig. 8). The $D$ value was $2.90 \mathrm{~min}$ ('Kiyomi') and $1.88 \mathrm{~min}$ ('Kawano-natsudaidai') for APDBD treatment of fungal infection on the pericarps of the fruit (Fig. 5), and $2.42 \mathrm{~min}$ for APDBD-treatment of the fruit surface 


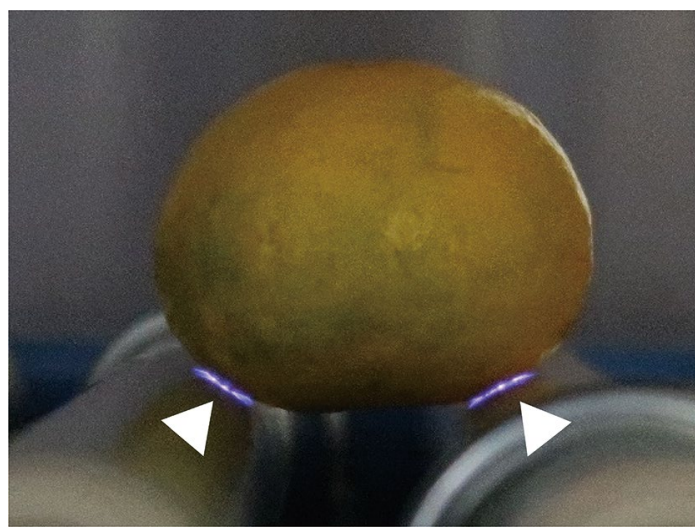

Fig. 7 Emission observed during APDBD treatment of citrus fruit. An emission (purple light) is clearly visible between the surface of the electrodes and C. unshiu (arrowheads) during APDBD treatment using the roller conveyor plasma instrument

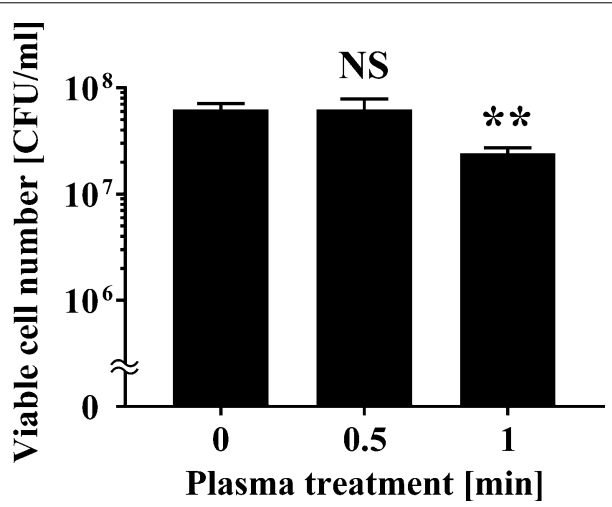

Fig. 8 Viable cell number of $P$. venetum on the surface of $C$. unshiu following APDBD treatment. Viable cell numbers of $P$. venetum, expressed as CFU per $\mathrm{ml}$, on the surface of contaminated C. unshiu at individual APDBD treatment times $(0,0.5$, or $1 \mathrm{~min})$ are shown. Differences where $p<0.01\left(^{* *}\right)$ versus control $(0 \mathrm{~min})$ were considered significant when verified by the non-repeated measured ANOVA followed by the Bonferroni correction. NS means no significant difference compared to Control (0 min)

(Fig. 8). Thus, the disinfection efficiency of APDBD treatment is far superior to that of $P$. digitatum by UV-C treatment $(D$ value $=26.2 \mathrm{~min})$ (Iseki et al. 2010). These findings suggest that the roller conveyor type plasma instrument is useful for the surface disinfection of citrus fruits contaminated with fungi. In addition, APDBD treatment causes damage to the DNA of Penicillium as well as Aspergillus, because in both cases the plasma treatment results in decreased levels in intact DNA (Figs. 3 and 4). These observations suggest that DNA damage may, at least in part, contribute to the inactivation mechanism of APDBD treatment. Interestingly, the
$D$ value was significantly longer for plasma treatment of Penicillium spotted on the pericarp or surface of a citrus fruit compared with Penicillium spotted onto an aluminium plate. In addition, two classes of citrus pericarps showed different $D$ values. Thus, the disinfection efficiency might depend on the surface material and agricultural products on which the fungi are located. However, the present study used a limited number of treatment conditions with only two classes of agricultural products and a control material. Moreover, slight variations in the initial fungal cell number, arising from lot-to-lot variation in fungal culture preparation, may have occurred. Thus, further investigation into the disinfection effect using a broad range of agricultural products and surface materials together with the corresponding effective treatment time at a variety of initial fungal cell numbers is required to confirm the difference of $D$ value between abiotic and biotic surfaces as well as among agricultural products.

The mechanisms by which the instrument disinfects fungi remains unclear. Plasma can be produced by introduction of a high electric field to gases. The resultant partially ionized gases form plasma, which contain dissociated molecules, positive and negative ions, photons, and electrons, as well as reactive chemical species (Shintani et al. 2010). In our previous study using a roller conveyer plasma instrument, we employed optical emission spectroscopy and chemical indicators to detect reactive oxygen and nitrogen species (RONS) such as peroxynitrite $\left(\mathrm{ONOO}^{-}\right)$and hydrogen peroxide $\left(\mathrm{H}_{2} \mathrm{O}_{2}\right)$ during operation of the instrument (Toyokawa et al. 2017). Several reports have shown that reactive chemical products generated by plasma disinfection techniques appears to contribute to inactivating fungi (Los et al. 2020). This hypothesis is supported by our results, which show that plasma generated by a roller conveyer plasma instrument induces changes in the fungal DNA (Figs. 3 and 4). Similarly, treatment with other plasma instruments that generate nitrogen gas plasma (BLP-TES) result in oxidation of genomic DNA mediated by reactive chemicals species (Sakudo et al. 2017a).

The present system using a roller conveyer plasma instrument can be applied to agricultural crops after harvesting to control infection during the sorting process. However, it is not known whether this treatment has a deleterious effect on the various agricultural products. Further investigation is required before practical application of this new technology can proceed. In addition, fungi produce metabolites, including mycotoxins that display carcinogenic and mutagenic activity (Sakudo et al. 2017b; Pankaj et al. 2018). It is possible that operation of the roller conveyor plasma instrument might inactivate these mycotoxins. 
In conclusion, our study suggests that the novel roller conveyer plasma system can efficiently disinfect the surface of citrus fruits contaminated with fungi. We believe the roller conveyer plasma device could be used to disinfect citrus fruits after harvesting during the sorting process.

\section{Supplementary Information}

The online version contains supplementary material available at https://doi. org/10.1186/s13568-020-01177-2.

Additional file 1: Figure S1. Voltage waveforms during operation of the roller conveyer plasma instrument.

\section{Acknowledgments}

The authors would like to acknowledge Ms. Risa Yamashiro, Mr. Yoichi Toyokawa, Mr. Genyuu Naka, and Mr. Shingo Teruya (University of the Ryukyus, Japan) for technical assistance.

\section{Authors' contributions}

$A S$ and $Y Y$ conceived and designed research. AS and $Y Y$ conducted experiments and analyzed data. AS contributed analytical experiments. AS and YY wrote the manuscript. Both authors read and approved the final manuscript.

\section{Funding}

This work was supported by a Grant-in-Aid for the Promotion of Basic Research Activities for Innovative Biosciences from the Bio-oriented Technology Research Advancement Institution (BRAIN), and the Science and Technology Research Promotion Program for Agriculture, Forestry, Fisheries and Food Industry. The study was also supported by KAKENHI grant numbers JP16K04997, JP20K03919, and JP24110717 from Japan Society for the Promotion of Science; and grant number 09-002-76 and 10-003-009 from Takahashi Industrial and Economic Research Foundation.

\section{Availability of data and materials}

All the relevant data used to support the findings of this study are included within the article.

\section{Ethics approval and consent to participate}

Not applicable.

\section{Consent for publication}

Not applicable.

\section{Competing interests}

The authors declare that they have no conflict of interest.

\section{Author details}

1 School of Veterinary Medicine, Okayama University of Science, Imabari, Ehime, Japan. ${ }^{2}$ Laboratory of Biometabolic Chemistry, School of Health Sciences, University of the Ryukyus, Nishihara, Okinawa, Japan. ${ }^{3}$ Department of Electrical and Electric Engineering, Sasebo National College of Technology, Sasebo, Nagasaki 857-1193, Japan.

Received: 24 September 2020 Accepted: 30 December 2020 Published online: 09 January 2021

\section{References}

Afshari R, Hosseini H (2014) Non-thermal plasma as a new food preservation method, Its present and future prospect. J Paramed Sci 5:116-120

Allende A, Selma MV, López-Gálvez F, Villaescusa R, Gil MI (2008) Role of commercial sanitizers and washing systems on epiphytic microorganisms and sensory quality of fresh-cut escarole and lettuce. Post Harvest Biol Technol 49:155-163
Amini M, Ghoranneviss M (2016) Effects of cold plasma treatment on antioxidants activity, phenolic contents and shelf life of fresh and dried walnut (Juglans regia L.) cultivars during storage. LWT 73:178-184

Bermudez-Aguirre D (ed) (2017) Ultrasound: Advances in food processing and preservation. Academic Press, Cambridge

Bermudez-Aguirre D (ed) (2019) Advances in cold plasma applications for food safety and preservation. Academic Press, Cambridge

Braný D, Dvorská D, Halašová E, Škovierová H (2020) Cold atmospheric plasma: a powerful tool for modern medicine. Int J Mol Sci 21(8):2932

Charoux CMG, Patange A, Lamba S, O'Donnell CP, Tiwari BK, Scannell AGM (2020) Applications of nonthermal plasma technology on safety and quality of dried foodingredients. J Appl Microbiol. https://doi. org/10.1111/jam.14823

Chen X, Hung Y (2017) Effects of organic load, sanitizer pH and initial chlorine concentration of chlorine-based sanitizers on chlorine demand of fresh produce wash waters. Food Control 77:96-101

FAO (Food and Agriculture Organization of the United Nations) and WHO (World Health Organization) (2016) Guidelines on highly hazardous pesticides, International code of conduct on pesticide management 2016. http://www.who.int/whopes/resources/9789241510417/en/. Accessed 24 Aug 2020

Garner AL (2019) Pulsed electric field inactivation of microorganisms: from fundamental biophysics to synergistic treatments. Appl Microbiol Biotechnol 103:7917-7929

Huang L, Zhang M, Yan W, Mujumdar AS, Sun D (2009) Effect of coating on post-drying of freeze-dried strawberry pieces. J Food Eng 92:107-111

Iseki S, Ohta T, Aomatsu A, Ito M, Kano H, Higashijima Y, Hori M (2010) Rapidinactivation of Penicillium digitatum spores using high-density nonequilibriumatmospheric pressure plasma. Appl Phys Lett 96(15):153704

Ito M, Oh JS, Ohta T, Shiratani M, Hori M (2018) Current status and future prospects of agricultural applications using atmospheric pressure plasma technologies. Plasma Process Polym 15(2):1700073

Kim JE, Lee DU, Min SC (2014) Microbial decontamination of red pepper powder by cold plasma. Food Microbiol 38:128-136

Kim JE, Oh YJ, Won MY, Lee KS, Min SC (2017a) Microbial decontamination of onion powder using microwave-powered cold plasma treatments. Food Microbiol 62:112-123

Kim JW, Puligundla P, Mok C (2017b) Effect of corona discharge plasma jet on surface-borne microorganisms and sprouting of broccoli seeds. J Sci Food Agric 97:128-134

Lee T, Puligundla P, Mok C (2018) Intermittent corona discharge plasma jet for improving tomato quality. J Food Eng 223:168-174

Los A, Ziuzina D, Boehm D, Cullen PJ, Bourke P (2020) Inactivation efficacies and mechanisms of gas plasma and plasma-activated water against Aspergillus flavus spores and biofilms: A comparative study. Appl Environ Microbiol 86(9):e02619-e2719

Manzocco L, Pieve SD, Bertolini A, Bartolomeoli I, Maifreni M, Vianello A, Nicoli MC (2011) Surface decontamination of fresh-cut apple by UV-C light exposure: effects on structure, colour and sensory properties. Postharvest Biol Technol 61(2-3):165-171

Ministry of Agriculture, Forestry and Fisheries, Tree area, yield and shipment of mandarin oranges produced in the first year of Reiwa (in Japanese) (2020). https://www.maff.go.jp/j/tokei/kekka_gaiyou/sakumotu/sakky ou_kajyu/mikan/r1/index.html. Accessed 24 Aug 2020

Moisan M, Barbeau J, Moreau S, Pelletier J, Tabrizian M, Yahia LH (2001) Lowtemperature sterilization using gas plasmas: a review of the experiments and an analysis of the inactivation mechanisms. Int J Pharm 226:1-21

Molnár H, Bata-Vidács I, Baka E, Cserhalmi Z, Ferenczi S, Tömösközi-Farkas R, Adányi N, Székács A (2018) The effect of different decontamination methods on the microbial load, bioactive components, aroma and colour of spice paprika. Food Control 83:131-140

Nakashima R, Kawamoto M, Miyazaki S, Onishi R, Furusaki K, Osaki M, Kirisawa R, Sakudo A, Onodera T (2017) Evaluation of calcium hydrogen carbonate mesoscopic crystals as a disinfectant for influenza A viruses. J Vet Med Sci 79:939-942

Ogawa T, Nakatani A, Matsuzaki H, Isobe S, Isshiki K (2000) Combined effects of hydrostatic pressure, temperature, and the addition of allyl isothiocyanate on inactivation of Escherichia coli. J Food Prot 63:884-888

Pankaj SK, Shi H, Keener KM (2018) A review of novel physical and chemical decontamination technologies for aflatoxin in food. Trends Food Sci Technol 71:73-83 
Rahman S, Khan I, Oh D (2016) Electrolyzed water as a novel sanitizer in the food industry: current trends and future perspectives. Compr Rev Food Sci Food Saf 15(3):471-490

Rico D, Martín-Diana AB, Barat JM, Barry-Ryan C (2007) Extending and measuring the quality of fresh-cut fruit and vegetables: a review. Trends Food Technol 18:373-386

Sakudo A, Shintani H (eds) (2010) Sterilization and disinfection by plasma: sterilization mechanisms, biological and medical applications (medical devices and equipment). Nova Science Publishers, New York

Sakudo A, Toyokawa Y, Nakamura T, Yagyu Y, Imanishi Y (2017a) Nitrogen gas plasma treatment of bacterial spores induces oxidative stress that damages the genomic DNA. Mol Med Rep 15:396-402

Sakudo A, Toyokawa Y, Misawa T, Imanishi Y (2017b) Degradation and detoxification of aflatoxin $B_{1}$ using nitrogen gas plasma generated by a static induction thyristor as a pulsed power supply. Food Control 73:619-626

Sakudo A, Yagyu Y, Onodera T (2019) Disinfection and sterilization using plasma technology: fundamentals and future perspectives for biological applications. Int J Mol Sci 20(20):5216

Sakudo A, Yamashiro R, Haritani M, Furusaki K, Onishi R, Onodera T (2020a) Inactivation of non-enveloped viruses and bacteria by an electrically charged disinfectant containing meso-structure nanoparticles via modification of the genome. Int J Nanomedicine 15:1387-1395

Sakudo A, Iwamaru Y, Furusaki K, Haritani M, Onishi R, Imamura M, Yokoyama T, Yoshikawa Y, Onodera T (2020b) Inactivation of scrapie prions by the electrically charged disinfectant CAC-717. Pathogens 9(7):536

Savary S, Ficke A, Aubertot JN, Hollie C (2012) Crop losses due to diseases and their implications for global food production losses and food security. Food Security 4:519-537

Shintani H, Sakudo A, Burke P, McDonnell G (2010) Gas plasma sterilization of microorganisms and mechanisms of action. Exp Ther Med 1:731-738

Shintani H, Sakudo A (eds) (2016) Gas plasma sterilization in microbiology: theory, applications, pitfalls and new perspectives. Caister Academic Press, London

Strange RN, Scott PR (2005) Plant disease: a threat to global food security. Ann Rev Phytopathol 43:83-116
Toyokawa Y, Yagyu Y, Misawa T, Sakudo A (2017) A new roller conveyer system of non-thermal gas plasma as a potential control measure of plant pathogenic bacteria in primary food production. Food Control 72:62-72

Toyokawa Y, Yagyu Y, Yamashiro R, Ninomiya K, Sakudo A (2018) Roller conveyer system for the reduction of pesticides using non-thermal gas plasma-A potential food safety control measure? Food Control 87:211-217

Uemura K, Isobe S (2002) Developing a new apparatus for inactivating Escherichia coli in saline water with high electric field AC. J Food Eng 53:203-207

Venta MB, Broche SSC, Torres IF, Pérez MG, Lorenzo EV, Rodriguez YR, Cepero SM (2010) Ozone application for postharvest disinfection of tomatoes. Ozone Sci Eng 32(5):361-371

Wang Y, Yi J, Yi J, Dong P, Hu X, Liao X (2013) Influence of pressurization rate and mode on inactivation of natural microorganisms in purple sweet potato nectar by high hydrostatic pressure. Food Bioprocess Technol 6:1570-1579

Wang CY, Huang HW, Hsu CP, Yang BB (2016) Recent advances in food processing using high hydrostatic pressure technology. Crit Rev Food Sci Nutr 56:527-540

WHO (World Health Organization) \& FAO (Food and Agriculture Organization of the United Nations) (1996) Report of the joint meeting of the FAO panel of experts on pesticide residues in food and the environment and the WHO Expert group on pesticide residues. http://www.fao.org/docre p/W3727E/w3727e00.htm\#Contents/. Accessed 24 Aug 2020

Won MY, Lee SJ, Min SC (2017) Mandarin preservation by microwave-powered cold plasma treatment. Innov Food Sci Eng Technol 39:25-32

Yagyu Y, Hatayama Y, Hayashi N, Mishima T, Nishioka T, Sakudo A, Ihara T, Ohshima T, Kawasaki H, Suda Y (2016) Direct plasma disinfection of green mold spore on citrus by atmospheric pressure dielectric barrier discharge for agricultural applications. Trans Mat Res Soc Japan 41(1):127-130

\section{Publisher's Note}

Springer Nature remains neutral with regard to jurisdictional claims in published maps and institutional affiliations.

\section{Submit your manuscript to a SpringerOpen ${ }^{\circ}$ journal and benefit from:}

- Convenient online submission

- Rigorous peer review

- Open access: articles freely available online

- High visibility within the field

Retaining the copyright to your article

Submit your next manuscript at $\boldsymbol{\nabla}$ springeropen.com 